\title{
PENGARUH PEMBELAJARAN NILAI-NILAI PANCASILA TERHADAP PRILAKU MAHASISWA DI STIK BINA HUSADA
}

\author{
Oleh: \\ Sari Misnaini \\ STIK Bina Husada Palembang \\ $\underline{\text { misnaini.sarii@gmail.com }}$
}

\begin{abstract}
ABSTRAK
Kondisi bangsa Indonesia sekarang sedang dilanda oleh berbagai krisis, yang tidak mendukung tumbunya suburnya pengamalan nilai-nilai Pancasila. Hal ini terlihat dari masih maraknya masalah narkoba, tawuran, pola hidup konsumerisme, praktik hidup keagamaan yang mementingkan formalisme yuridis dan simbol-simbol yang memudahkan untuk diadu domba. Krisis karakter sekarang ini sudah menjalar pada lingkungan kampus yang tampak pada sikap dan perilaku mahasiswa yang bertentangan dengan nilai moral. Oleh sebab itu sebagai manusia yang menjunjung keharmonisan dan keserasian sebagai jati diri bangsa maka sangatlah tepat jika nilainilai Pancasila dijadikan sebagai nilai moral untuk landasan dalam menjalani kehidupan bermasyarakat, berbangsa dan bernegara khusunya kehidupan kampus Bina Husada. Prinsip etika Pancasila pada hakikatnya bersifat humanistik, artinya nilai-nilai Pancasila mendasarkan pada nilai yang bersumber pada harkat dan martabat manusia sebagai makhluk yang berbudaya. Pancasila sebagai dasar negara dan ideologi bangsa mengandung nilai ketuhanan, nilai kemanusiaan, nilai persatuan, nilai kerakyatan dan nilai keadilan. Melalui pembelajaran Pancasila di kampus Bina Husada , mahasiswa mulai menyaadai akan pengamalan nilai-nilai Pancasila. Dari pengamalan inilah ditemukan perubahan-perubahan perilaku ke arah yang lebih baik.
\end{abstract}

\section{ABSTRACT}

The condition of the Indonesian nation is now being hit by various crises, which do not support the growth of the practice of Pancasila values. This is evident from the still rampant drug problems, brawls, consumerism patterns, religious life practices that emphasize juridical formalism and symbols that make it easier to pitted the sheep. The current character crisis has spread to the campus environment that appears to the attitudes and behaviors of students as opposed to moral values. Therefore, as a man who uphold harmony and harmony as national identity, it is appropriate if the values of Pancasila serve as a moral value for the foundation in living the life of society, nation and state especially the life of Bina Husada campus. The ethical principle of Pancasila is essentially humanistic, meaning that Pancasila values are based on values derived from the dignity of human beings as cultured beings. Pancasila as the basis of state and ideology of the nation contains the value of divinity, human values, the value of unity, the value of democracy and the value of justice. Through the learning of Pancasila at Bina Husada campus, students begin to pursue the practice of Pancasila values. It is from these practices that behavioral changes are found in a better direction.

\section{A. PENDAHULUAN}

Pendidikan pancasila dimaknai sebagai pendidikan nilai, pendidikan moral, pendidikan budi pekerti, pendidikan watak, dan pendidikan akhlak dengan tujuan untuk mengembangkan kemampuan

peserta didik dalam memberikan keputusan baik-buruk, memelihara sesuatu yang baik, dan mewujudkan kebaikan di kehidupan sehari-hari. Pendidikan pancasila sebagai konsep pendidikan melibatkan aspek pengetahuan (cognitive), perasaan (feeling), serta tindakan (action). Dengan kata lain dalam pendidikan pancasila, sistem penanaman nilai-nilai kebaikan kepada warga sekolah atau kampus tidak hanya berpusat pada aspek pengetahuan saja, melainkan juga pada aspek kesadaran atau kemauan, serta tindakan untuk melaksanakan nilai-nilai tersebut sehingga menjadi manusia yang seutuhnya.

Sekolah Tinggi Ilmu Kesehatan Bina Husada Palembang merupakan sebuah 
Lembaga Pendidikan kesehatan, utamanya pada Program Studi Kesehatan Masyarakat yang didirikan untuk mencetak tenagatenaga kesehatan yang memenuhi standar kesehatan, profesional, kepribadian serta sosial dengan berlandaskan keilmuan dan keislaman. Kesehatan masyarakat merupakan bidang studi yang membelajarkan materi- materi abstrak dan numerik, dimana materi-materi tersebut merupakan tema yang tepat untuk memacu karakter seseorang sehingga menjadi cikal bakal sumber daya manusia berkualitas. Melalui pendidkan pancasila,seseorang akan mau dan mampu berpikir untuk mengkaji suatu permasalahan secara logis dan sistematis.

Kualitas pendidikan pancasila ditandai oleh kualitas lulusan perguruan tinggi, artinya kualitas lulusan sekolah tinggi kesehatan merupakan cermin dari kualitas kampus itu sendiri. Setiap pendidik sebagai lulusan perguruan tinggi dituntut memiliki kemampuan dalam membina karakter peserta didik. Jadi, pembinaan karakter mahasiswa calon tenaga kesehatan merupakan bagian yang tidak terpisahkan dari pendidikan di kampus. Oleh karena itu, Sekolah tinggi kesehatan Bina Husada Pendidikan penghasil dan pengembang tenaga kesehatan yang berkepribadian islami dan berkarakter yang direalisasikan melalui implementasi nilai-nilai pancasila dalam pembelajaran pendidikan pancasila, namun selogan berkarakter belum dapat dilaksanakan dengan optimal. Realita di lapangan masih banyak ditemukan penyimpangan-penyimpangan perilaku sebagai bukti adanya kesenjangan antara indikator pencapaian nilai-nilai pancasila dengan pelaksanaan praktis di lapangan. Dengan demikian penelitian ini dilakukan untuk mengaji pengetahuan dan persepsi mahasiswa mengenai nilai- nilai pancasila dan pembelajaran mata kuliah pancasila dalam kehidupan sehari-hari di kampus, mengamati sekaligus mendeskripsikan bagaimana implementasi nilai-nilai pancasila yang sesungguhnya pada pembelajaran pancasila, mengetahui sekaligus menanggapi persepsi mahasiswa terkait implementasi nilai-nilai pancasila tersebut, serta menelaah perilaku mahasiswa sebagai indikator pencapaian tujuan implementasi nilai-nilai pancasila di Program Studi kesehatan masyarakat STIKES Bina Husada. Akhirnya, penelitian ini diharapkan dapat menjadi salah satu acuan dalam perencanaan, pelaksanaan, dan evaluasi dalam implementasi nilai-nilai pancasila pada pembelajaran secara umum, maupun pembelajaran pancasila secara khusus dengan bercermin pada persepsi-persepsi mahasiswa.

Fokus penelitian ini adalah pelaksanaan nilai-nilai pancasila pada STIK Bina Husada dan implimentasinya dalam kehidupan mahasiswa sehari-hari. Untuk itu dirumuskan permasalahan sebagai berikut:

1. Adakah pengaruh pembelajaran nilai-nilai pancasila pada kehidupan mahasiswa dalam kampus STIK Bina Husada Palembang.

2. Bagaimanakah persepsi nilai-nilai pancasila pada kehidupan mahasiswa STIK Bina Husada Palembang.

Sebelum penelitian ini diadakan, peneliti berhipotesis bahwa pembelajaran nilai-nilai Pancasila memiliki pengaruh tehadap prilaku mahasiswa di STIK Bina Husada Palembang

Pancasila sebagai salah satu mata kuliah yang memiliki tujuan "How to Develop Better Civics Behaviours" membekali mahasiswa untuk mengembangkan penalarannya disamping aspek nilai dan moral, banyak memuat materi sosial. Pancasila merupakan salah satu dari lima tradisi pendidikan IPS yakni citizenship transmission, saat ini sudah berkembang menjadi tiga aspek Pancasila (Citizenship Education), yakni aspek akademis, aspek kurikuler dan aspek sosial budaya. Secara akademis Pancasila dapat didefinisikan sebagai suatu bidang kajian yang 
memusatkan telaahannya pada seluruh dimensi psikologi dan sosial budaya kewarganegaraan individu dengan menggunakan ilmu politik dan pendidikan sebagai landasan kajiannya. Implementasiya sangat dibutuhkan dosen yang profesional, dosen yang profesional dituntut menguasai sejumlah kemampuan dan keterampilan, antara lain :

1. Kemampuan menguasai bahan ajar

2. Kemampuan dalam mengelola kelas

3. Kemampuan dalam menggunakan metode, media dan sumber belajar

4. Kemampuan untuk melakukan penilaian baik proses maupun hasil

Selanjutnya UNESCO dalam Soedijarto (2004 : 10-18) mencanangkan empat pilar belajar dalam pembelajaran, yaitu Learning to Know (penguasaan ways of knowing or mode of inquire), Learning to do ( controlling, monitoring, maintening, designing, organizing), Learning to live together, dan Learning to be .

\section{B. KAJIAN TEORI DAN METODE}

\section{Pengertian Implimentasi Pancasila}

Elkind dan Sweet (dalam Kemendiknas, 2010:13) menyebutkan implimentasi atau pendidikan dimaknai sebagai berikut: "character education is the deliberate effort to help people understand, care about, and act upon core ethical values". Implimentasi atau pendidikan pancasila adalah suatu usaha sengaja untuk membantu orang memahami, peduli dan bertindak menurut nilai-nilai etika. Sementara itu menurut Ramli (dalam Kemendiknas, 2010:13), implimentasi atau pendidikan pancasila memiliki esensi dan makna yang sama dengan implimentasi atau pendidikan moral dan pendidikan akhlak. Tujuannya adalah membentuk pribadi anak, supaya menjadi manusia yang baik, warga masyarakat, dan warga negara yang baik.

Pendidikan moral dan pendidikan karakter tidaklah sama. Perbedaannya terletak pada ruang lingkup dan lingkungan yang membantu individu dalam mengambil keputusan. Dalam pendidikan moral, ruang lingkupnya adalah kondisi batin seseorang. Sedangkan dalam pendidikan karakter ruang lingkupnya selain terdapat dalam diri individu, juga memiliki konsekuensi kelembagaan, yang keputusannya tampil dalam kinerja dan kebijakan lembaga pendidikan (Koesoema, 2010:198).

Dalam implimentasi nilai-nilai Pancasila bukan hanya sekedar bernilai pendidikan mengkondisi batin seseorang tetapi bagaimana nilai-nilai Pancasila itu menjadi karakter seseorang, melembaga, dan mewarnai setiap kebijakan.

\section{Nilai-nilai Setiap Sila dalam Pancasila}

Nilai-nilai Pancasila yaitu nilai-nilai yang terkandung dalam setiap sila-sila Pancasila dimana antara sila-sila tersebut saling berkaitan dan secara utuh tidak dapat dipisahkan yang dijadikan suatu ukuran, patokan anggapan dan keyakinan yang menjadi panutan orang dan kelompok atau masyarakat bangsa Indonesia. Nilai-nilai moral yang terkandung dalam pancasila pada hakikatnya merupakan kesatuan moral bangsa Indonesia. Pancasila sebagai dasar falsafah negara berarti bahwa moral bangsa telah menjadi moral negara yaitu mengikat negara sekaligus mengandung arti telah menjadi sumber tertib negara dan sumber tertib hukum serta jiwa seluruh kegiatan negara dalam segala aspek kehidupan negara.

Sebagai dasar dan ideologi negara, nilai-nilai yang terkandung didalam sila-sila Pancasila itu antara lain sebagai berikut :

a. Nilai Ideologi, sebagai pandangan dan sikap hidup.

b. Nilai Politik, sumber dari segala hukum di Indonesia.

c. Nilai Ekonomi, perekonomian disusun sebagai usaha bersama berdasarkan atas kekeluargaan.

d. Nilai Sosial, mewujudkan keadilan sosial bagi seluruh rakyat Indonesia.

e. Nilai Kebudayaan, memiliki nilai luhur dari budaya bangsa Indonesia. 
Pancasila sebagai norma terdiri dari lima norma sebagai tercantum pada lima sila pancasila:

a. Ketuhanan Yang Maha Esa

b. Kemanusiaan Yang Adil dan Beradab

c. Persatuan Indonesia

d. Kerakyatan Yang Dipimpin Oleh Hikmat Kebijaksanaan

Dalam Permusyawaratan/Perwakilan

e. Keadilan Sosial Bagi Seluruh Rakyat Indonesia

Kelima sila dalam Pancasila di atas agar lebih mudah diwujudkan atau diimplimentasikan dalam kehidupan seharihari digali nilai-nilai sebagai berikut.

Ketuhanan Yang Maha Esa

a. Percaya dan taqwa kepada Tuhan Yang Maha Esa sesuai dengan agama dan kepercayaannya masing-masing menurut dasar kemanusiaan yang adil dan beradab.

b. Hormat dan menghormati serta bekerjasama antara pemeluk agama dan penganut-penganut kepercayaan yang berbeda-beda sehingga terbina kerukunan hidup.

c. Saling menghormati kebebasan menjalankan ibadah sesuai dengan agama dan kepercayaan masing-masing.

d. Tidak memaksakan suatu agama atau kepercayaannya kepada orang lain.

Kemanusiaan Yang Adil Dan Beradab

a. Mengakui persamaan derajat, persamaan hak dan persamaan kewajiban antara sesama manusia.

b. Saling mencintai sesama manusia.

c. Mengembangkan sikap tenggang rasa.

d. Tidak semena-mena terhadap orang lain.

e. Menjunjung tinggi nilai kemanusiaan.

f. Gemar melakukan kegiatan kemanusiaan.

g. Berani membela kebenaran dan keadilan.

h. Bangsa Indonesia merasa dirinya sebagai bagian dari masyarakat Dunia Internasional dan dengan itu harus mengembangkan sikap saling hormatmenghormati dan bekerjasama dengan bangsa lain.
Persatuan Indonesia

a. Menjaga Persatuan dan Kesatuan Negara Kesatuan Republik Indonesia.

b. Rela berkorban demi bangsa dan negara.

c. Cinta akan Tanah Air.

d. Berbangga sebagai bagian dari Indonesia.

e. Memajukan pergaulan demi persatuan dan kesatuan bangsa yang ber-Bhinneka Tunggal Ika.

Kerakyatan Yang Dipimpin Oleh Hikmat

Kebijaksanaan

Dalam

\section{Permusyawaratan/Perwakilan}

a. Mengutamakan kepentingan negara dan masyarakat.

b. Tidak memaksakan kehendak kepada orang lain.

c. Mengutamakan budaya rembug atau musyawarah dalam mengambil keputusan bersama.

d. Berembug atau bermusyawarah sampai mencapai konsensus atau kata mufakat diliputi dengan semangat kekeluargaan.

Keadilan Sosial Bagi Seluruh Rakyat Indonesia

a. Bersikap adil terhadap sesama.

b. Menghormati hak-hak orang lain.

c. Menolong sesama.

d. Menghargai orang lain.

e. Melakukan pekerjaan yang berguna bagi kepentingan umum dan bersama

Pancasila merupakan moral, individu bangsa indonesia dan karena telah ditetapkan sebagai dasar negara maka Pancasila sekaligus menjadi moral negara yang mengatur sikap dan tingkah laku setiap individu.

a. Sila pertama mewajibkan untuk mengakui dan memuliakan Tuhan Yang Maha Esa

b. Sila kedua mewajibkan untuk mengakui dan memperlakukan semua, dan setiap orang sama tanpa alasan atau diskriminasi

c. Sila ketiga mewajibkan untuk menjunjung tinggi dan mencintai tanah air, bangsa dan negara indonesia, ikut memperjuangkan kepentingankepentingannya, mengambil sikap yang solider dan layak terhadap sesama warga negara. 
d. Sila keempat mewajibkan untuk ikut serta dalam kehidupan politik serta pemerintahan negara.

e. Sila kelima mewajibkan untuk bersikap adil, berjiwa sosial, memberikan sumbangan yang wajar sesuai dengan kemampuan dan kedudukan orangperorang masing-masing kepada negara demi terwujudnya kesejahteraan lahir batin bagi seluruh rakyat indonesia.

\section{Contoh Implementasi Pancasila dalam Kehidupan Kampus}

Kampus juga harus memerlukan tatanan pembangunan seperti tatanan Negara yaitu politik, ekonomi, budaya, hukum dan antar umat beragama. Sebagai mahasiswa yang mempunyai rasa intelektual yang besar kita dapat memanfaatkan fasilitas kampus untuk mencapai tujuan bersama.

Implementasi Sila I : Ketuhanan yang Maha Esa

a. Jadwal kuliah sudah diatur sedemikian rupa sehingga tidak mengganggu jadwal untuk beribadah.

b. Mahasiswa baru diwajibkan untuk mengikuti ospek/pengenalan kampus.

c. UKM ( Unit Kegiatan Mahasiswa) kerohanian, misalnya UKM mahasiswa Budha, Kristen, Katolik, Protestan, Islam dan Hindhu.

Implementasi Sila II : Kemanusiaan yang adil dan beradab

a. Mahasiswa dalam kampus berasal dari berbagai macam latar belakang: Budaya, Agama, Ras, dan Suku Bangsa

b. Tidak ada pembedaan perlakuan/diskriminasi dalam kampus.

c. Semua mahasiswa diperlakukan secara adil dan sama.

Implementasi Sila III : Persatuan Indonesia

a. Melalui organisasi kemahasiswaan membentuk suatu jaringan perkumpulan mahasiswa dari berbagai universitas di Indonesia.

b. Hal tersebut merupakan salah satu bukti ada sikap dan upaya untuk memjalin rasa kebersamaan diantara para mahasiswa sebagai bagian dari pemuda Indonesia.
Implementasi Sila IV : Kerakyatan yang Dipimpin oleh Hikmat Kebijakanaan dalam Permusyawaratan/Perwakilan

Penerapan suatu kebiasaan untuk melakukan musyawarah dan diskusi bersama terkait dengan berbagai hal merupakan cerminan yang tepat dalam implementasi sila ke-4:

a. Rapat UKM

b. Diskusi dalam kelas

c. Musyawarah penunjukkan ketua BEM

d. Pemilihan ketua Senat Mahasiswa

e. dan lain- lain.

Implementasi Sila $V$ : Keadilan Sosial Bagi Seluruh Rakyat Indonesia

Penerapan persamaan dan saling menghargai karya orang lain :

a. Mahasiswa yang telah memenuhi syarat berhak untuk mengikuti ujian akhir semester

b. Setiap mahasiswa berhak memperoleh nilai sesuai dengan kemampuannya

c. Setiap mahasiswa berupaya menghargai hasil karya orang lain dengan tidak mencontek atau membuat plagiat atas hasil karya ilmiah teman. (http://yogawinasis.web.ugm.ac.id/2016/0 4/19)

Berdasarkan permasalahan di atas, maka tujuan utama penelitian ini adalah untuk mengetahui pengaruh pembelajaran nilainilai pancasila terhadap prilaku mahasiswa di STIK Bina Husada. Dari hasil penelitian ini diharapkan bermanfaat bagi pemetaan permasalahan kehidupan berbangsa dan bernegara khususnya di kampus STIK Bina Husada, sekaligus menjadi dasar penguatan penerapan atau implimentasi nilai-nilai Pancasila di kalangan mahasiswa.

\section{Metodologi}

Penelitian ini menggunakan metode deskriptif kualitatif, yakni penelitiannya dilakukan pada kondisi yang alamiah (natural setting) (Sugiyono, 2011:14). Alasan menggunakan metode ini adalah calon peneliti bermaksud mendapatkan pemahaman secara lebih mendalam tentang 
pelaksanaan dan implimentasinya pada mahasiswa STIK Bina Husada Palembang.

Penelitian ini dilaksanakan pada STIK Bina Husada Palembang. Waktu penelitian direncanakan akan dilaksanakan selama 3 (tiga) bulan terhitung sejak penyusunan proposal penelitian hingga perbaikan (Oktober-Desember 2017). Sumber data dalam penelitian ini adalah angket dan tes yang dilakukan secara serempak. Data dianalisis secara interaktif dan berlangsung secara terus-menerus sampai datanya sudah jenuh. Aktivitas dalam analisis data mengikuti flow model yang dikemukakan oleh Miles dan Huberman (Sugiyono, 2011:337), yaitu data reduction, data display dan conclusion drawing/verification .

Peneliti melakukan pengumpulan data melalui kegiatan anticipatory sebelum melakukan reduksi data. Selanjutnya model interaktif dalam analisis data seperti gambar di bawah ini:

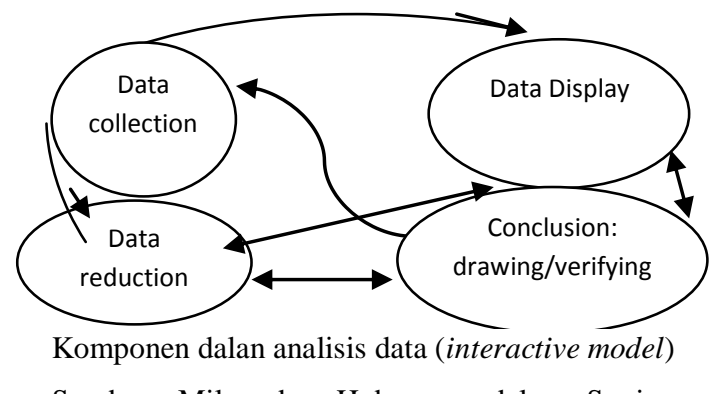

Sumber: Miles dan Huberman dalam Sugiyono (2011: 338)

Dalam pemeriksaan dan pengecekan keabsahan data peneliti akan menggunakan teknik pemeriksaan seperti yang dikemukakan oleh Sugiyono (2011:367-378) yakni: 1) Credibility (Derajat Kepercayaan) yaitu perpanjangan pengamatan, peningkatan ketekunan dalam penelitian, tringulasi, diskusi dengan teman sejawat, analisis kasus negative, menggunakan bahan referensi, dan member check.2) Transferability (keteralihan) yaitu mendeskripsikan secara rinci, jelas, dan sistematis temuan-temuan yang diperolah di lapangan ke dalam format yang telah disiapkan. 3) Dependability (kebergantungan) adalah melakukan audit keseluruhan aktivitas peneliti dalam melakukan penelitian.4) Confirmability (kepastian) adalah menguji hasil penelitian, dikaitkan dengan proses yang dilakukan

\section{HASIL PENELITIAN DAN PEMBAHASAN}

Dalam penelitin ini telah dilakukan dengan mengadakan kegitan pretes dan postes untuk melihat seberapa besar pengaruh pembelajaran terhadap tingkat pemahaman mahasiswa terhadap nilai-nilai Pancasila. Begitu pula halnya dengan pengaruhnya terhadap perilaku atau pengamalan nilai-nila Pancasila dalam kehidupan sehari-hari di kampus, yaitu dilakukan dengan penyebaran angket sebelum pembelajaran dan setelah proses pembelajaran Pancasila.

\section{Pemahaman Nilai-Nilai Pancasila Di STIK Bina Husada Sebelum Pengajaran Pancasila}

Penerapan atau Implementasi nilai-nilai Pancasila dalam kegiatan pembelajaran di kamnpus sangat penting untuk dilaksanakan meskipun Pancasila atau PKn telah diajarkan sejak SD. Hal ini juga sesuai dengan Undang-Undang Nomor 20 Tahun 2003 pasal 2 yaitu pendidikan nasional berdasarkan Pancasila dan Undangundang Dasar 1945. Pelemahan implimentasi itu tidak terlepas dari berbagai pengaruh intern dan ekstern pada mahasiswa itu sendiri. Oleh sebab itu sebagai gambaran awal sebelum Pancasila diajarkan kepada mahasiswa diadakan pretes kepada mahasiswa PSKm semester 1 tahun 2017 yang hasilnya dapat dilihat pada tabel berikut ini.

Tabel 1

Pemahaman Nilai-nilai Pancasila Sebelum Pembelajaran

\begin{tabular}{|c|l|l|}
\hline No & Sila Pancasila & Rataan Nilai \\
\hline 1 & Pertama & 79,46 \\
\hline 2 & Kedua & 53,17 \\
\hline 3 & Ketiga & 68,45 \\
\hline 4 & Keempat & 51,79 \\
\hline 5 & Kelima & 20,78 \\
\hline Rataan & 54,73 \\
\hline
\end{tabular}


Berdasarkan tabel 1 di atas, sila pertama (Ketuhanan yang Maha Esa) sudah cukup baik pemahamannya $(79,46)$, sila kedua (kemanusiaan yang adail dan beradab) masih rendah $(53,17)$, Sila ketiga (Persastuan Indonesia) masih tergolong cukup $(68,45)$, sila keempat (Kerakyatan yang Dipimpin oleh Hikmat Kebijakasanaan dalam permusyawaratan/perwakilan) masih rendah $(51,79)$ sila kelima (Keailan Sosial bagi Seluruh Rakyat Indonesia) masih sangat rendah dengan rataan 20,78. Rata-rata pemahaman terhadap nilai-nilai Pancasila menunjukkan nilai 54,73 atau tergolong rendah.

2. Pemahaman Nilai-nilai Pancasila di STIK Bina Husada Setelah Pembelajaran Pancasila

Mahasiswa PSKM Bina Husadah semester 1 tahun 2017/2018 selama satu semester mendapat perkuliahan Pancasila. Dalam proses perkuliahan itu hingga hampir satu semester ternyata telah mengalami peningkatan pemahaman terhadap nilai-nilai Pancasila. Peningkatan tersebut lebih jelas dapat dilihat pada tabel 2 berikut.

Tabel 2

Pemahaman Nilai-nilai Pancasila Setelah Pembelajaran

\begin{tabular}{|l|l|l|}
\hline No & $\begin{array}{l}\text { Sila } \\
\text { Pancasila }\end{array}$ & $\begin{array}{l}\text { Rataan } \\
\text { Nilai }\end{array}$ \\
\hline 1 & Pertama & 95,72 \\
\hline 2 & Kedua & 86,23 \\
\hline 3 & Ketiga & 84,98 \\
\hline 4 & Keempat & 90,64 \\
\hline 5 & Kelima & 87,66 \\
\hline \multicolumn{2}{|l}{ Rataan } & 88,44 \\
\hline
\end{tabular}

Berdasarkan tabel 2 di atas dapat diketahua bahwa pemahaman nilaia-nilai Pancasila setelah dilakukan pembelajaran mengalami peningkatan yang cukup signifikan baik pemahaman terhadap nilainilai setiap sila mauipun secara keseluruhan. Pemahaman terhadap sila sila pertama (Ketuhanan yang Maha Esa) sudah sangat baik pemahamannya $(95,72)$, sila kedua (kemanusiaan yang adail dan beradab) sangat baik $(86,23)$, Sila ketiga (Persastuan Indonesia) sangat baik $(84,98)$, sila keempat (Kerakyatan yang Dipimpin oleh Hikmat Kebijakasanaan dalam permusyawaratan/perwakilan) ssangat baik $(90,64)$ sila kelima (Keailan Sosial bagi Seluruh Rakyat Indonesia) sangat baik $(87,66)$. Kenaikan itu menytebabkan Ratarata pemahaman terhadap nilai-nilai Pancasila juga mengalamim kenaikan yang signifikan yaitu rataan nilai 88,44 atau tergolong sangat baik. Untuk lebih jelas peningkatan pemahaman tersebut dadpat dlihat pada tabael berikut.

Tabel 3

Peningkatan Pemahaman Mahasiswa Terhadap Nilai-nilai Pancasila Setelah Proses Pembelajaran

\begin{tabular}{|l|l|l|l|l|}
\hline No & $\begin{array}{l}\text { Sila } \\
\text { Pan } \\
\text { Casi } \\
\text { la }\end{array}$ & $\begin{array}{l}\text { Rata } \\
\text { an } \\
\text { Nilai } \\
\text { Sebe } \\
\text { lum }\end{array}$ & $\begin{array}{l}\text { Rataa } \\
\text { nilai } \\
\text { Sete } \\
\text { lah }\end{array}$ & $\begin{array}{l}\text { Peni } \\
\text { ng } \\
\text { kata } \\
\text { n } \\
\text { Pem } \\
\text { a } \\
\text { ham } \\
\text { an }\end{array}$ \\
\hline 1 & I & 79,46 & 95,72 & 16,26 \\
\hline 2 & II & 53,17 & 86,23 & 30,06 \\
\hline 3 & III & 68,45 & 84,98 & 18,53 \\
\hline 4 & IV & 51,79 & 90,64 & $\begin{array}{l}38, \\
85\end{array}$ \\
\hline 5 & V & 20,78 & 87,66 & 66,88 \\
\hline \multicolumn{2}{|l|}{ Rataan } & 54,73 & 88,44 & 34,12 \\
\hline
\end{tabular}

Pada tabel 3 di atas ada peningkatan yang paling tinggi yaitu pemahaman terhadap nilai-nilai pancasila sila ke 5 , yaitu 66,88 , dari nilai 20,78 menjadi 87,66; kemudian sila keempat 38,85 ; sila kedua 30,06 ; sila ketiga 18,85 ; sedangkan terendah pada sila pertama, yaitu 16,26.Namun demikian pemahaman terhadap sila pertama menempati nilai tertinggi yaitu 95,72. Sedangkan peningkatan pemahaman nilainilai Pancasila secara keseluruhan yaitu 34,12 dari rataan 54,73 menjadi 88,44. 


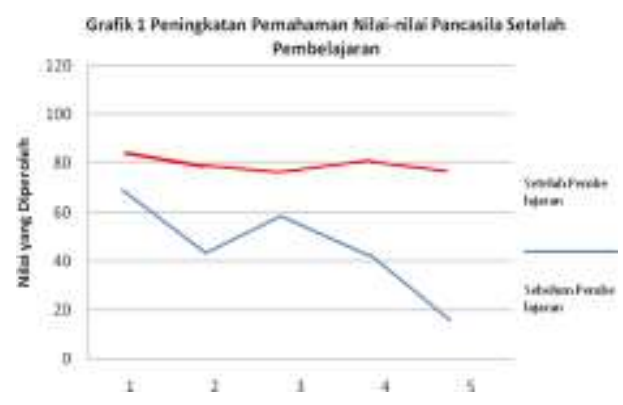

3. Pengamalan Nilai-nilai Pancasila di STIK Bina Husada dalam Kehidupan Kampus sebelum Pembelajaran

Mahasiswa PSKM mengikuti perkuliahan pada semester pertama tahun pembelajaran 2017/2018 berjumlah 32 orang adalah lulusan SMA memiliki latar belakang SMA yang berbeda-beda. Untuk mengetahui pengamalan mahasiswa terhadap nilai-nilai Pancasila yang sebenarnya maka disebarlah angket yang berupa pengakuan jujur mereka apakah nilai-nilai Pancasaila sudah diterapkan dalam kehidupan sehari-hari atau belum. Untuk mengetahui keadaan tersebut dalam kehidupan mahasiswa di kampus maka diadakanlah angket yang berisi nilai-nilai Pancasila dengan skala sikap sering atau selalu dilakukan (skor 4), kadang-kadang (3), jarang (2), dan tidak pernah (1). Berdasarkan hasil angket yang disebarkan kepada mahasiswa PSKM semester 1 sebelum mata kuliah Pancasila diajarkan dapaat dilihat pada tabel 4 beerikut.

Tabel 4

Pengamalan Nilai-nilai Pancasila di STIK Bina Husada dalam Kehidupan Kampus sebelum Diadakan Pembelajaran

\begin{tabular}{|l|l|c|}
\hline No & $\begin{array}{l}\text { Sila } \\
\text { Pancasila }\end{array}$ & $\begin{array}{c}\text { Rataan Skor } \\
\text { Jawaban }\end{array}$ \\
\hline 1 & Pertama & 3,02 \\
\hline 2 & Kedua & 2,93 \\
\hline 3 & Ketiga & 3,20 \\
\hline 4 & Keempat & 2,89 \\
\hline 5 & Kelima & 3,10 \\
\hline \multicolumn{2}{|l|}{ Rataan } & 3,02 \\
\hline
\end{tabular}

Berdasarkan tabel di atas implimentasi sila pertama (Ketuhanan yang Maha Esa) memperoleh skor 3,02 atau cukup baik. Implimentasi terhadap sila kedua (Kemanusiaan yang adil dan beradab) memperoleh skor 2,93 atau cukup. Implimentasi terhadap sila ketiga (Persatuan Indonesia) memperoleh skor 3,2 atau cukup baik. Implimentasi terhadap sila keempat (Kerakyatan yanag Dipimpin oleh Hikmat Kebijaksanaan dalam Permusyawaratan/Perwakilan) memperoleh skor 2,89 atau cukup. Implimentasi terhadap sila kellima (Keadilan Sosial bagi Seluruh Rakyat Indonesia) memperoleh skor 3,10 atau cukup baik.Sedangkan rataan pengamalan terhadap kellima sila Pancasila sduah cukup baik yaitu dengan sekor rataan 3,02 .

Untuk mengetahui pengamalan nilai-nilai Pancasila dalam kehidupan mahasiswa di kampus selama pembelajaran mata kuliah Pancasaila maka diadakanlah angket kembali yang berisi nilai-nilai Pancasila seperti angket sebelumnya yaitu dengan skala sikap sering atau selalu dilakukan (skor 4), kadang-kadang (3), jarang (2), dan tidak pernah (1). Angket ini disebarkan menjelang akhir perkuliahan atau pertemuan terakhir pada tanggal 11 Desember 2017. Untuk mengetahui hasil angket tersebut dapat dilihat pada tabel 5 berikut.

Tabel 5

Pengamalan Nilai-nilai Pancasila di STIK Bina Husada dalam Kehidupan Kampus Setela Proses Penbelajaran

\begin{tabular}{|l|l|c|}
\hline No & $\begin{array}{l}\text { Sila } \\
\text { Pancasila }\end{array}$ & $\begin{array}{c}\text { Rataan Skor } \\
\text { Jawaban }\end{array}$ \\
\hline 1 & Pertama & 3,88 \\
\hline 2 & Kedua & 3,81 \\
\hline 3 & Ketiga & 3,68 \\
\hline 4 & Keempat & 3,79 \\
\hline 5 & Kelima & 3,72 \\
\hline \multicolumn{2}{|l|}{ Rataan } & 3,78 \\
\hline
\end{tabular}

Berdasarkan hasil angket yang disebarkan kepada mahasiswa PSKM 
semester 1 implimentasi sila pertama (Ketuhanan yang Maha Esa) memperoleh skor 3,88 atau sangat baik. Implimentasi terhadap sila kedua (Kemanusiaan yang adiul dan beradab) memperoleh skor $\mathbf{3 , 8 1}$ atau sangat baik. Implimentasi terhadap sila ketiga (Persatuan Indonesia) memperoleh skor 3,68 atau sangat baik. Implimentasi terhadap sila keempat (Kerakyatan yanag Dipimpin oleh Hikmat Kebijaksanaan dalam Permusyawaratan/Perwakilan) memperoleh skor 3,79 atau sangat baik. Implimentasi terhadap sila kellima (Keadilan Sosial bagi Seluruh Rakyat Indonesia) memperoleh skor $\mathbf{3 , 7 2}$ atau sangat baik.

Terlihat pula bahwa implimentasi Pancasila dalam kehidupan di kampus yang paling tinggi adalah sila pertama (Ketuhanan yang Maha Esa), mencapai 3,88 atau sangat baik. Namun demikian bukan berarti sila-sila yang lain implimentasinya rendah, melainkann sila-sila yang lain juga telah dimplimentasi sangat baik dengan skor di atas 3,65 atau dengan skor rata-rata $\mathbf{3 , 7 8}$ atau sangat baik.

Seperti halnya pada pemahaman nilai-nilai Pancasila, penghayatan terhadap nilai-nilai Pancasila ini pun mengalami peningkatan setelah proses pembelajaran Pancasila, lebih jelas dapat dilihat pada tabel 6 berikut.

Tabel 6
$\begin{aligned} & \text { Peningkatan Pengamalan Tehadap Nilai- } \\
& \text { nilai Pancasila Setelah Diadakan } \\
& \text { Pembelajaran Pancasila }\end{aligned}$
\begin{tabular}{|l|l|c|c|c|}
\hline No & $\begin{array}{l}\text { Sila } \\
\text { Panc } \\
\text { asila }\end{array}$ & $\begin{array}{c}\text { Rataan } \\
\text { Skor } \\
\text { Sebelum } \\
\text { Pembela } \\
\text { jaran }\end{array}$ & $\begin{array}{c}\text { Rataan } \\
\text { Skor } \\
\text { Setelah } \\
\text { Pembel } \\
\text { a jaran }\end{array}$ & $\begin{array}{c}\text { Pe } \\
\text { ning } \\
\text { kata } \\
\text { n } \\
\text { Skor }\end{array}$ \\
\hline 1 & 1 & 3,02 & 3,88 & 0,86 \\
\hline 2 & 2 & 2,93 & 3,81 & 0,88 \\
\hline 3 & 3 & 3,20 & 3,68 & 0,48 \\
\hline 4 & 4 & 2,89 & 3,79 & 0,99 \\
\hline 5 & 5 & 3,10 & 3,72 & 0,62 \\
\hline \multicolumn{2}{|l|}{ Rataan } & 3,03 & 3,78 & 0,75 \\
\hline
\end{tabular}

Berdasaarkan tabel 6 di atas peningkatan pengamalan terhadap nilai-nilai Pencasila setelah diadakan proses pembelajaran atau perkuliahan Pancasila terjadi pada kelima sila Pancasila, dimulai dari peningkatan tertinggi pada sila keempat $(0,99)$, sila kedua $(0,88)$, sila kesatu $(0,86)$, sila kelima $(0,62)$, sila ketiga $(0,48)$, dan rataan kenaikan 0,75 . Lebih jelas lagi kenaikan tersebut dapat dilihat pada grafi 2 berikut.

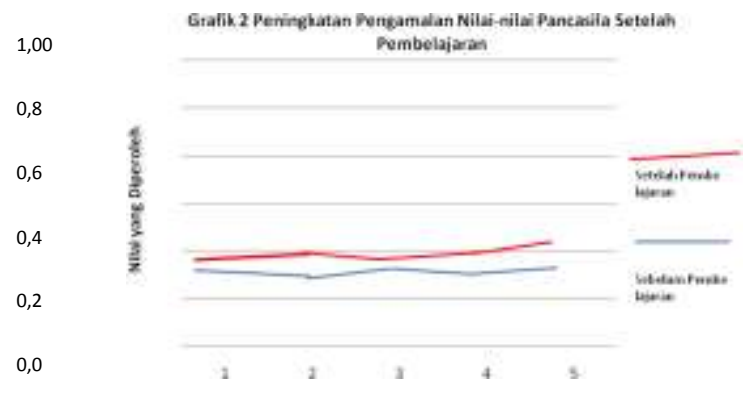

Apabila dilihat dari kedua aspek perubahan di atas ternyata melalui pembelajaran Pancasila maka pemahaman dan pengamalan nilai-nialai Pancasila daapat ditingkatkan. Melalui pembelajaran pemahaman mahasiswa terhadap nilai-nilai Pancasila meningkat dari 54,73 menjadi 88,44 sedangkan pengamalan atau implimentasi dalam kehidupan sehari-hari berdasarkan skala sikap naik dari 3,03 menjadi 3,78. Dengan kata lain bahwa pembelajaran Pancasila memberi pengaruh terhjadap pemahaman dan pengamalannya sehari-hari.

\section{SIMPULAN}

Berdasarkan uraian terdahulu dapat disimpulkan bahwa pembelajaran Pancasila memberi pengaruh yang signifikan terhadap perilaku mahasiswa dalam aktivitasnya di kampus dalam kehidupan sehari-hari. Hal ini terbukti dari hasil tes dan angket sebelum kegiatan pembelajaran atau perkulihan diberikan dan setelah perkuliahan Pancasila berlangsung.

1. Berdasarkan hasil tes pemahaman terhadap nilai-nilai Pancasila, pemahaman mahasiswa terhadap nilai- 
nilai Pancasila meningkat dari rata-rata 54,73 menjadi 88,44

2. Berdasarkan hasil angket implimentasi atau pengamalan terhadap nilai-nilai Pancasila dalam kehidupan sehari-hari meningkat dari skala sikap 3,03 menjadi 3,78 .

\section{DAFTAR PUSTAKA}

Kambey, D. C. (2006). Landasan teori administrasi/manajemen. Manado: Tri Ganesha Nusantara.

Koesoema, D. A. (2010). Pendidikan karakter: strategi mendidik anak di zaman global. Jakarta: Grasindo.

.(2012). Pendidikan Karakter Utuh dan Menyeluruh. Yogyakarta: Kanisius.

Kusdi. (2009). Teori organisasi dan sdministrasi. Jakarta: Salemba Humanika.

Megapolitan, Tawuran Antarpelajar, [Online]

(http://www.megapolitan.com, diakses 21 Desember 2012).

Moleong, Lexy, J. (2007). Metodologi penelitian kualitatif (Edisi Revisi). Bandung: PT Remaja Rosdakarya.

Mudyahardjo, R. (2001). Pengantar pendidikan. Jakarta: Raja Grafindo Persada.

Muslich, M. (2011). Pendidikan karakter: menjawab tantangan krisis multidimensional. Jakarta: Bumi Aksara.

Ratag, M. A. dan Korompis, R. (2009). Kurikulum Berbasis Kehidupan: Pandangan tentang Pendidikan Menurut Ronald Korompis. Tomohon: Yayasan Pendidikan Lokon.

Sagala, S. (2010). Manajemen strategik dalam peningkatan mutu pendidikan. Bandung: Alfabeta.

Sugiyono. (2011). Metode penelitian pendidikan, pendekatan kuantitatif, kualitatif dan $R \& D$. Bandung: Alfabeta.
Sule, E. T dan Saefullah, K. (2010). Pengantar manajemen. Jakarta: Kencana.

Tim Dosen Administrasi Pendidikan Universitas Pendidikan Indonesia. (2011). Manajemen Pendidikan. Bandung: Alfabeta.

Usman, H. (2011). Manajemen: teori, praktik, dan riset pendidikan. Jakarta: Bumi Aksara.

Wikipedia Indonesia, Manajemen, [Online] (http://id.wikipedia.org/wiki/Indonesi a.manajemen, diakses 5 April 2013).

Kaelan. (2002). Filsafat pancasila pandangan hidup bangsa indonesia: Yogyakarta. 